for the last 21 years as a member of the House of Lords. She had been one of the first women to be admitted to that House and the first to sit on the Woolsack as a Deputy Speaker. She was especially known for her studies and experience of the borderland of delinquency and mental abnormality. Her 'Social Science and Social Pathology' was a masterly review of what the social sciences had to say about those whose conduct-from whatever cause-became socially unacceptable. This year she would be delivering the College's Maudsley Lecture on the relation of law, medicine and deviance. While sometimes expressing doubts as to the 'scientific pretensions' of psychiatry, she had never lost sight of one aspect which she had summed up in a memorable sentence, ' . . . there can be no question of its humanizing effect upon the treatment of socially refractory persons . . . this humanizing influence is a good in itself, never to be discounted".

\section{Presidential Address and Distinguished Guest Lecture}

Professor Pond then gave a talk entitled 'Responsibility', (to be published in a forthcoming issue of the Bulletin.)
The Distinguished Guest Lecture, entitled 'Ibsen on Breaking Free from Ghosts, White Horses and Strangers of the Past' was given by Professor Russell Davis.

\section{SOCIAL EVENTS}

On 9 July members and guests were invited to a buffet supper at Exe Vale Hospital, Exminster, by the Regional and Area Health Authorities.

On 10 July a Reception was held in St George's Hall at the kind invitation of the Mayor and City of Exeter. This was followed by the Annual Dinner, at which Dr Gerald Timbury proposed the toast of 'The Guest' responded to by Professor D. Mattingly who then proposed the toast 'The Royal College of Psychiatrists'. The President replied on behalf of the College.

On 11 July the South Western Division of the College invited members and their wives/husbands to visit the Maritime Museum, Exeter and to a buffet supper. Earlier in the day members and guests had been invited on a coach trip to Powderham Castle.

On 12 July Mrs Pond received guests at home for tea.

\title{
ANNUAL SUBSCRIPTION 1980
}

This notice is to remind members who do not pay their annual subscriptions by Standing Order that they are due and payable on 1 January, and it would be helpful if you could let us have a remittance as quickly as possible. A subscription arrears notice will be prepared by the new computer early in 1980 and sent to members who have not paid by that time.

We are grateful to the many members who already pay their subscription by bank giro and hope that more members will consider payment in this way. I will be happy to supply the appropriate form.

Members whose remittance takes the form of drafts or cheques in currencies other than sterling must ensure that the College receives the FULL subscription and should add 50p to the amount due to cover the charges or bank costs which the College will have to meet on realization.
The annual subscriptions for 1980 are:

Fellows and Foundation Fellows

$£ 60.00$

Members and Foundation Members $\quad £ 40.00$

Affiliates

$£ 25.00$

Inceptors

$£ 10.00$

Corresponding Associates $\quad \mathbf{£ 1 5 . 0 0}$

Joint Membership:

Total of two subscriptions minus $£ 10.00$

(receive one Joumal)

Retired (Fellows/Members/Affiliates/

Corresponding Associates):

Retired before 1 January 1976

Retired after 1 January 1976

$€ 12.00$

Over 40 years' membership
Nil

C. M. B. PARE

Honorary Treasurer

\section{CURT P. RICHTER PRIZE}

Through the generosity of the Irish Foundation for Human Development, an Annual Prize has been established for research in psychoneuroendocrinology. The aim is to encourage research by younger scientists, and the sum of $\$ 1,000$ will be awarded annually for the best manuscript or essay submitted by a scientist under 35 years of age. The winning paper will be published in Psychoneuroendocrinology. Entries should be submitted in triplicate no later than I April 1980 to Dr Fleur L. Strand, Secretary, International Society of Psychoneuroendocrinology, Biology Department, New York University, Washington Square, NY 10003, U.S.A. 


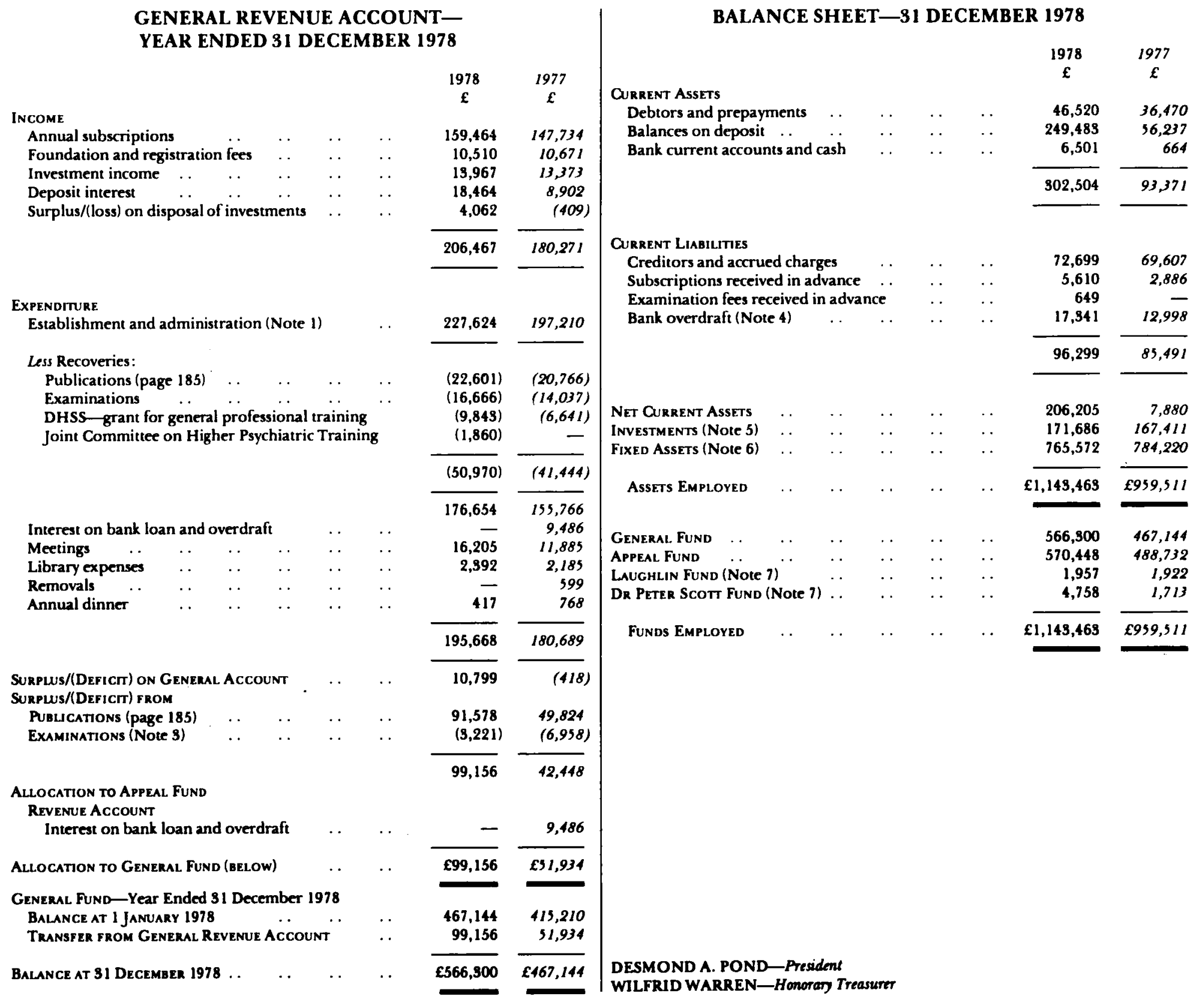




\section{STATEMENT OF SOURCE AND APPLICATION OF FUNDS-YEAR ENDED 31 DECEMBER 1978}

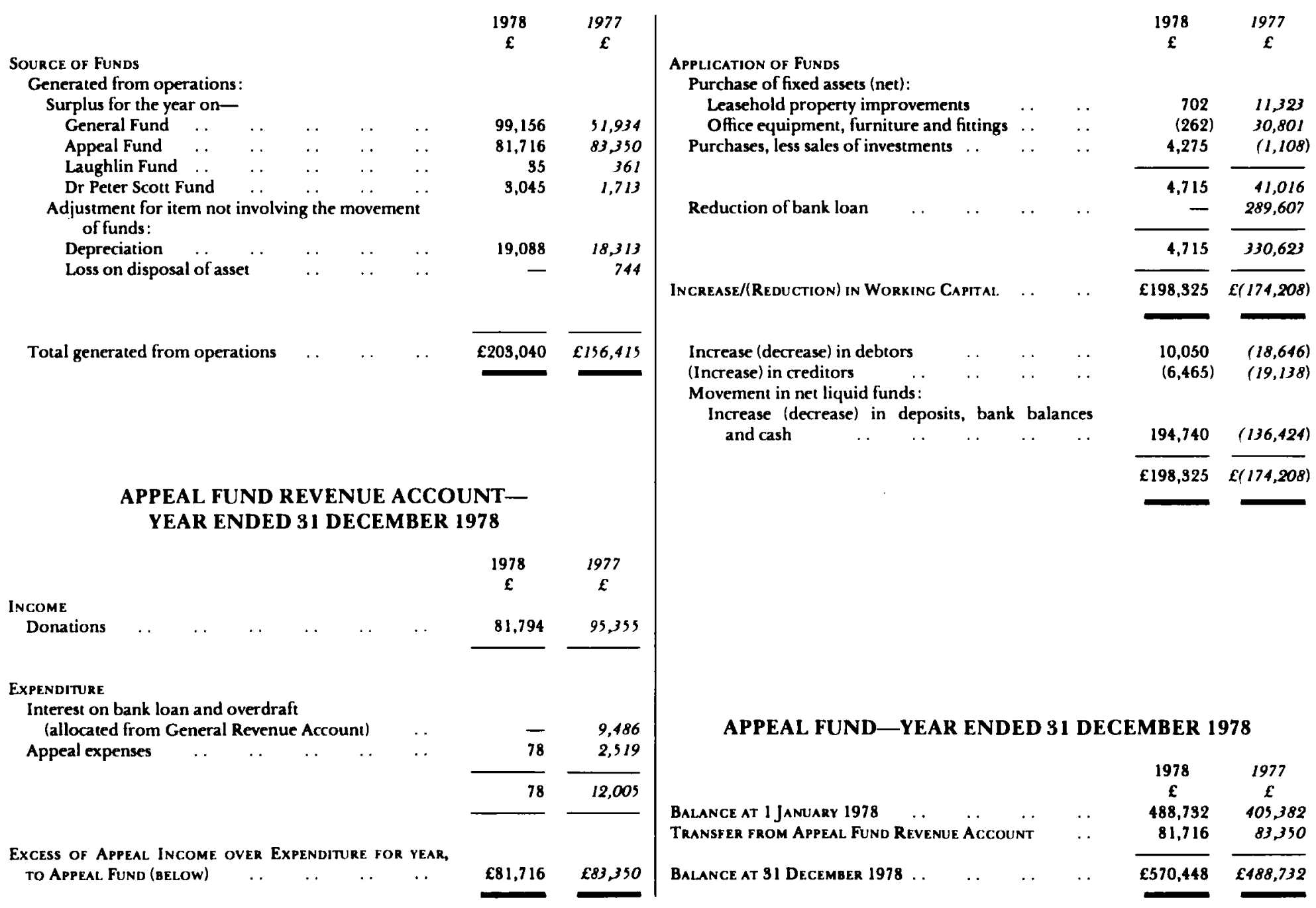


BRITISHJOURNAL OF PSYCHIATRY AND SPONSORED PUBLICATIONS INCOME AND EXPENDITURE ACCOUNT_YEAR ENDED 31 DECEMBER 1978 INCOME
Subscription for journal received in year (Note 2)
Special publications ..

Back numbers and reprints

Advertisements

Release of copyrights, net

Sale of miscellaneous books Value added tax recovered

\begin{tabular}{|c|c|c|c|c|c|c|c|c|}
\hline $\begin{array}{c}1978 \\
\epsilon\end{array}$ & $\begin{array}{l}1977 \\
E\end{array}$ & & & & & & $\begin{array}{c}1978 \\
f\end{array}$ & $\begin{array}{c}1977 \\
f\end{array}$ \\
\hline & & \multicolumn{7}{|l|}{ EXPENDITURE } \\
\hline 181,478 & 134,284 & \multicolumn{7}{|l|}{ Printing expenses : } \\
\hline 4,463 & 4,537 & \multirow{2}{*}{$\begin{array}{r}\text { Journal-Text } \quad . \\
\text { —Advertising }\end{array}$} & $\ldots$ & $\ldots$ & . & .. & 36,941 & 36,964 \\
\hline 2,505 & 3,078 & & . . & . & . & . . & 25,245 & 23,435 \\
\hline & & \multirow{3}{*}{$\begin{array}{l}\text { Bulletin . . } \\
\text { Special publications }\end{array}$} & .. & .. & . & .. & 9,228 & 6,821 \\
\hline $\begin{array}{r}188,446 \\
53,328\end{array}$ & $\begin{array}{r}141,899 \\
46,059\end{array}$ & & .. & .. & . & .. & 2,024 & 4,368 \\
\hline 660 & 759 & & & & & & 73,438 & 71,588 \\
\hline 242,434 & 188,717 & \multicolumn{2}{|c|}{ Postage, wrapping and despatch } & & & & 23,014 & 18,505 \\
\hline 1,413 & - & Publisher's commission & . & . & .. & .. & 27,401 & 20,270 \\
\hline 522 & 512 & Administration charge & .. & .. & . & .. & 22,601 & 20,766 \\
\hline & & Staff costs $\quad \ldots$ & .. & .. & .. & .. & 3,650 & 1,762 \\
\hline \multirow{5}{*}{$£ 244,369$} & $f 189,229$ & Meetings & $\cdots$ & $\cdots$ & $\cdots$ & $\cdots$ & 551 & 874 \\
\hline & & \multirow{3}{*}{$\begin{array}{l}\text { Sundry expenses } \quad . \\
\text { Miscellaneous publications }\end{array}$} & .. & .. & . & .. & 2,136 & 1,973 \\
\hline & & & & . & . & . & - & 3,667 \\
\hline & & & & & & & 152,791 & 139,405 \\
\hline & & \multicolumn{4}{|c|}{ Surplus carried to General. Revenue Account } & . & $£ 91,578$ & $£ 49,824$ \\
\hline
\end{tabular}




\section{NOTES ON THE ACCOUNTS—YEAR ENDED 31 DECEMBER 1978}

1. Establishment and Administration Expenses

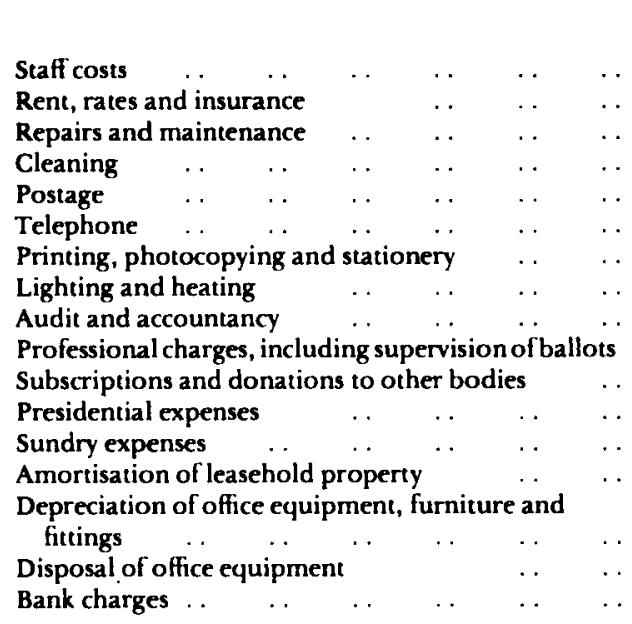

2. British Journal. of Psychiatry

No credit is taken in The British Joumal of Psychiatry Income and Expenditure Account for copies of the Joumal supplied to members free of charge.

3. Examinations

\begin{tabular}{|c|c|c|}
\hline \\
\hline & & \multirow{3}{*}{$\begin{array}{l}28,448 \\
35,406\end{array}$} \\
\hline & & \\
\hline & \multirow{2}{*}{$\begin{array}{r}33,860 \\
37,081 \\
E(3,221)\end{array}$} & \\
\hline 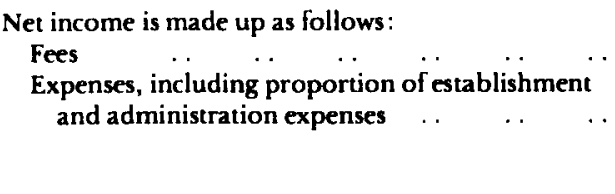 & & $\mathcal{E}(6,958)$ \\
\hline
\end{tabular}

4. Bank Overdraf

Overdraft facilities up to a limit of $£ 200,000(1977-£ 300,000)$ are available, secured by a charge on the leasehold premises of the College.

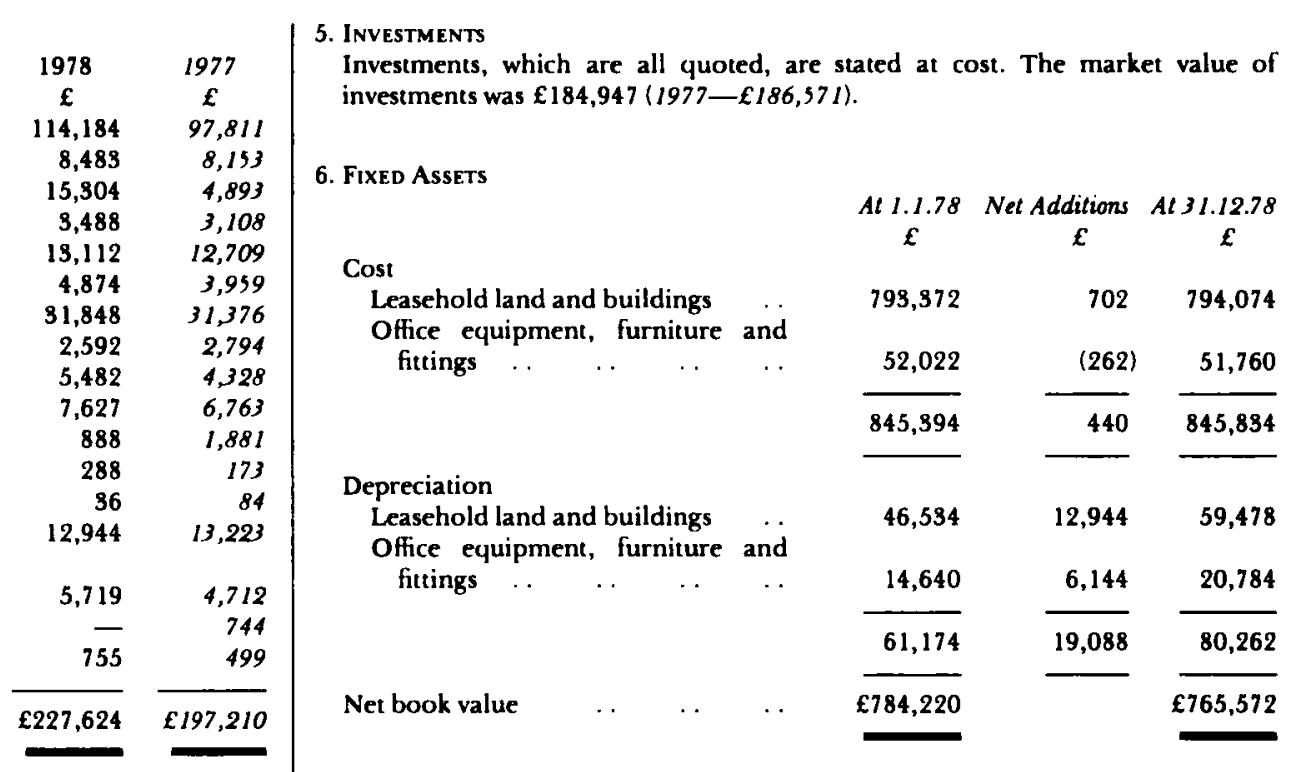

Land and buildings are held on a lease expiring in 2034 ; the cost is being amortised over the period of the lease.

Depreciation of office equipment, furniture and fittings is pravided as follows Computer $15 \%$ p.a. on cost Other equipment $\quad 10 \%$ p.a. on cost

\section{Funds for Spectfic Purposes}

Movements during the year were as follows

Opening balance

Donations .

Investment income

Closing balances

\begin{tabular}{|c|c|}
\hline $\begin{array}{c}\text { Laughlin } \\
\text { Fund } \\
\mathbb{E} \\
1,922\end{array}$ & $\begin{array}{c}\text { Dr Peter } \\
\text { Scott Fund } \\
£ \\
1,713\end{array}$ \\
\hline 35 & 2,913 \\
\hline - & 132 \\
\hline$£ 1,957$ & $£ 4,758$ \\
\hline
\end{tabular}




\section{THE GASKELL MEMORIAL FUND}

\section{REVENUE ACCOUNT-YEAR ENDED 31 DECEMBER 1978}

\begin{tabular}{|c|c|c|}
\hline \multicolumn{3}{|l|}{ INCOME } \\
\hline Investment and bank interest & . & . \\
\hline \multicolumn{3}{|l|}{ EXPENDITURE: } \\
\hline Prizes & .. & .. \\
\hline Medals and engraving & .. & .. \\
\hline Examination fees and expenses & .. & .. \\
\hline Publicity expenses & .. & .. \\
\hline
\end{tabular}

SURPLUS/(DEFICIT) FOR YEAR Balance Brought Forward

Balance Carried Forward

\begin{tabular}{|c|c|}
\hline $\begin{array}{c}1978 \\
f\end{array}$ & $\begin{array}{c}1977 \\
\boldsymbol{E}\end{array}$ \\
\hline 157 & 156 \\
\hline 75 & 75 \\
\hline 43 & 26 \\
\hline 45 & 45 \\
\hline 121 & - \\
\hline 284 & 146 \\
\hline $\begin{array}{l}(127) \\
(120)\end{array}$ & $\begin{array}{c}10 \\
(130)\end{array}$ \\
\hline$f(247)$ & $E(J 20)$ \\
\hline
\end{tabular}

$$
\mid
$$

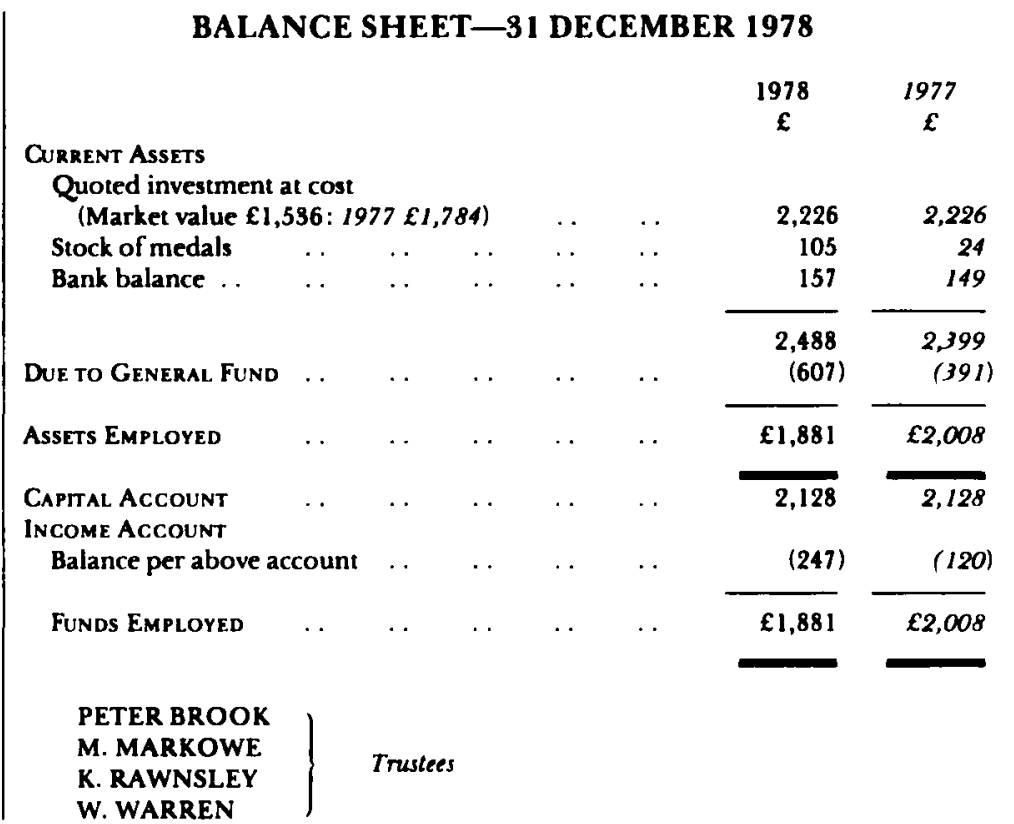

\section{REPORT OF THE AUDITORS}

We have examined the accounts of The Royal College of Psychiatrists and the Gaskell Memorial Fund and obtained all the information and explanations that we consider necessary for the purpose of our audit. The accounts have been prepared under the historical cost convention.

In our opinion the accounts give a true and fair view of the state of affairs at 31 December 1978 and of the surplus and source and application of funds for the year then ended. 